\title{
Contradictions of Financial Capital Switching: Reading the Corporate Leverage Crisis through The Port of Liverpool's Whole Business Securitization
}

Forthcoming in International Journal of Urban and Regional Research

\author{
Callum Ward \\ Bartlett School of Planning \\ University College London \\ callum.ward@ucl.ac.uk
}

\begin{abstract}
David Harvey argued there to be an animating tension at the heart of the geographical dynamics of capital: a simultaneous need for both spatial fixity and perpetual motion. I adapt this frame for an era of financial globalization, arguing that fixity has been overcome through a 'quaternary circuit' of credit-mediated capital switching which undermines the distinct roles of the three circuits Harvey identified. However, rather than resolving the fixity/motion contradiction this has instead given it intensified form as capital liquidity versus spatial fixity. I explore this through the Port of Liverpool's innovative 'Whole Business Securitization', tracing out the logic of leverage underpinning financial capital switching and how such practices transform the spatio-temporality of circulation while fostering the conditions for greater crises. By theorizing financial globalization from a capital switching perspective, this article combines Minskian and relational approaches to understanding investment chains in a way that reprises geographical political economy's critique of the territoriality of capitalist crisis.
\end{abstract}

Key words: Financialization, Infrastructure, Securitization, Port of Liverpool, Peel Ports, Whole Business Securitization, Financial Crisis, Corporate Leverage, Capital Switching, Brexit 


\section{The Fuse}

'The sub-prime timebomb is back - this time companies are lighting the fuse' announced The Observer in early 2019 (Makortoff 2019). In recent years international governance organizations have repeatedly warned that a bubble in corporate debt poses a significant threat to the stability of the global financial system (Bank of England, 2018a; European Central Bank, 2019; IMF, 2019). Yet despite regulatory attempts to rein in loose lending practices, corporate bond-issuance has grown 2.5 times over the last decade to a comparable size to that of the sub-prime mortgage market in 2007 (Bank of England, ibid). Amidst intensifying political economic volatility more generally, corporate sector overleverage is a potential trigger point of another financial crisis.

This article contextualizes the corporate leverage crisis by reinterpreting Harvey's $(1978 ; 1982)$ capital switching framework for an era of financialization. I argue that the obstacles to investment in the built environment which Harvey identified as 'spatial fixity' have been ameliorated through credit-mediated financial innovations. The super-profits from this have facilitated the absorption of overaccumulated capital into both the built environment and new spheres of speculation such as derivative markets (Aalbers 2008; Feagin 1987; Jessop 2015; Weber, 2015; Wijburg 2019; Yrigoy 2018). This 'financialization fix' (Fernandez and Wigger 2016) has transformed the global economy to such an extent that Aalbers (2008) characterized the ubiquity of financial capital switching as a 'quaternary circuit' of capital.

I outline what such a circuit entails by drawing on recent work on how asset abstraction through 'monetary' or 'wealth' chains (Alami 2018; Bryan et al. 2017; Ouma 2018; Pike and Pollard 2010; Pryke and Allen 2019; Sokol 2017; Wigan 2009; Wigan and Seabrooke 2017) has transformed the spatio-temporality of capital circulation. However, in so overcoming the features of spatial fixity Harvey identified, this endemic capital switching does not resolve capital's fixity/motion tension but instead introduces an intense set of contradictions that are inherent to the process of creating capital liquidity (Gotham 2009; 2012). Specifically, the creation of liquidity through fictitious capital brings to the fore the credit-driven asset inflation dynamics which Minsky (1982) identified (see Jessop 2015; Mian and Sufi 2014; Turner 2015). In theoretically unpacking this, the paper combines recent scholarship on relational wealth chains and Minskian analyses of financial instability within a Marxist geographical political economy framework. 
I explore this empirically through an innovative case of infrastructure financialization. Through a close reading of Peel Ports Groups 'Whole Business Securitization', I illustrate how financial engineering is used to create globally-circulable investment products from otherwise spatiallyfixed, idiosyncratic port infrastructure. I point to how the proliferation and systematization of 'risk' that this creation of capital liquidity rests on are likely sources of instability once expectations are confounded by the uncertainties of the sociospatial process - as appears to be the case following Britain's vote to leave the European Union. Going beyond cases of overleverage as reckless speculation (Aalbers et al. 2017; Pani and Holman 2014; Van Meeteren and Bassens 2018), then, the case shows how a relatively risk-averse company contributes to creating the conditions for crisis not because of individual imprudence but the inherent contradictions of credit-mediated capital liquidity.

By so synthesising recent strands of financial geography into a capital switching perspective on financialization, this paper offers an interpretive frame through which to analyse the geographies of contemporary economic instability. In the first section, I outline core features of Harvey's (1978; 1982/2006) theory, arguing that financialization has transformed the fixity/motion tension and corresponding dynamics of capital switching he identified. I draw on Aalbers' (2008) notion of a 'quaternary circuit of capital switching' to connect Harvey's theoretical framework to recent work conceptualising finance as relational chains (Bryan et al. 2017; Seabrooke and Wigan 2017; Sokol 2017) and Minskian analyses of the inherent instability of extensive credit issuance (Jessop 2015; Mian and Sufi 2014; Minsky 1982; Turner 2015). In the second section, an overview of Peel Ports Groups' whole business securitization illustrates the methods by which capital liquidity is created from fixed infrastructure assets, and the logic of leverage (Konings 2018) they adopt in doing so. In the final section I discuss how this illuminates the theory by demonstrating the ways in which the temporalities of capital circulation are transformed and the conditions of crisis fostered through Peel's credit-mediated liquidity creation.

\section{Creating Capital Liquidity out of Spatial Fixity}

Harvey $(1978 ; 2006)$ highlights one particular contradiction as central to the capitalist making of geography: fixity versus motion (see also Brenner, 1998; Jessop, 2000). If capital is stationary in 
any form it is vulnerable to devaluation, so a constant drive towards motion is borne of the corresponding imperative for rapid and easy exchange. Spatial fixity, meanwhile, is:

a condition of non-exchangeability, non-transferability, immobility, illiquidity and long turnover times between buying and selling... [it] also refers to a commodity that has diverse, idiosyncratic, and inconsistent properties such that it is difficult for buyers and sellers to know the value of what they are exchanging (Gotham 2012: 27)

The built environment is very much fixed in this sense as the barriers to investing in it are high with large upfront costs recovered over decades while the idiosyncrasies of investing in something so spatially bounded mean that returns are highly uncertain. As such, investment gravitates to the shorter turnover times and predictable markets of commodity production (the primary circuit of capital). However, fundamental instability in production ultimately generates surfeits of capital which cannot find profitable outlet. This 'overaccumulated' capital is devalued when unable to turnover within an acceptable time at an acceptable rate of profit so, under such conditions, finds refuge in the longer turnover times of fixed capital and the built environment (the 'secondary circuit of capital'). Thus, investment into the built environment occurs primarily through capitalism's 'spatial fix' in which crises of capital accumulation are deferred through massive investment into real estate and infrastructure.

The process of such a fix entails that current patterns of accumulation are reshaped through a 'switching crisis' which 'involve a major reorganization and restructuring of capital flows and/or major restructuring of mediating institutions in order to open up new channels for productive investment' in new geographical or sectoral spheres (Harvey, 1978: 112). Such large-scale capital switching is necessarily speculative and occurs through financial channels. This is the temporal moment of the spatial fix (see also Jessop 2000): crisis in one area is staved off through speculative financial intermediation. 'Capital switching' therefore denotes the restructuring of established valorization processes which, on large scale, creates new economic geographies.

Harvey conceptualized capital circuit restructuring as occurring through a switching crisis because the barriers of entry into the built environment mean that any such large-scale restructuring would occur as a result of crises. However, empirical work from the 1980 s onwards has shown the switching of capital to be chronic feature of accumulation as much as a convulsive response 
to crisis (Aalbers, 2007; Beauregard, 1994 Feagin, 1987; Newman 2009; Weber 2015). Aalbers (2008) attributes this to the development of a 'quaternary circuit of capital' in which financial capital switching becomes an accumulation strategy in- and for- itself, moving investments between and within the other three circuits while extracting value. In this view, the cross-border investment flows entailed by financial globalization has transformed the role of finance in the economy '...from its conventionally-defined, if always crisis-prone, intermediary function in the circuit of capital to a more dominant role oriented to rent extraction through financial arbitrage and innovation' (Jessop, 2015: 34). Capital switching has not only become routinized but the dominant strategy of accumulation (see Krippner 2012; Weber 2015).

The fundamental change here is that financial globalization (and associated innovations in finance) has ameliorated the tension of fixity versus motion in favor of the latter through the creation of capital liquidity. 'Capital liquidity' entails the ability to exchange an investment, either by conversion to cash or its trade on secondary markets. Financial innovations such as securitization, debt structuring (see Mian and Sufi, 2014), and Real Estate Investment Trusts (REITs) (Gotham, 2012) reduced barriers to investment and lowered the turnover time of capital in the built environment as real estate and infrastructure became 'just another asset class' (Van Loon and Aalbers, 2017). With such assets instantly tradeable through derivative products on secondary markets, international capital markets integrate markets and production on a world scale hitherto impossible, creating a 'tendentially complete world market' (Jessop 2015; see Bryan and Rafferty, 2006). Financial globalization, then, is a triumph of capital's impetus towards motion, overcoming spatial fixity through the construction of new credit-mediated circuits of accumulation.

Harvey plays with two entwined meanings of 'circuit': sectoral and geographical (see Kutz, 2016). The latter refers to the sociospatial configurations and technical processes through and around which capital is valorized, forming a 'structured coherence' of spaces within which economic processes, class relations and cultural life 'hang together' (Harvey 1985: 329; see Jessop 2000). Established such geographical coherences are disrupted and reshaped in the process of a spatial fix. The 'financialization fix' (Fernandez and Wigger 2016) has its own spatiality distinct to the nation-state focus of the Keynesian-era, as the creation of assets requires close city-regional scale 
management alongside international legal frameworks and technologies for their global circulation (Allen and Pryke 2019; Brenner 1998; Swyngedouw 2005; Torrance 2009).

In their work on 'global wealth chains' Seabrooke and Wigan (2017) identify how these new financial structured coherences have entailed the forging of distinct geographies, temporalities and institutional complexes to those of global production networks/value chains. Focusing on asset abstraction (and therein overlapping with recent literature on 'assetization', per Birch 2017), the use of the concept of global wealth chains is to 'target fluidity by incorporating the critical role of finance in mobilising, giving liquidity to, and commensurating value and wealth' (Bryan et al. 2017: 59), particularly paying attention to the ways in which 'earlier spatio-temporal logics are being transcended' (ibid: 78). Unpacking this within a capital switching framework points to how the nature of capitalism and its contradictions have been transformed in the process of creating these new financialized circuits.

This leads us to the sectoral sense in which Harvey, building directly on Marx, uses the concept of circuits to distinguish between primary, secondary, tertiary circuits based on the variable temporalities of different forms of capital. In this, to talk of a circuit of chronic capital switching is not to posit a simple additional circuit to Harvey's original three. Rather, the quaternary circuit represents their negation as the arbitrage of differing temporalities through credit '... lowers the socially necessary turnover time of capital, and changes the temporalities of the circuits of capital' (Jessop 2015: 26). The distinct temporalities between the circuits are undermined to the extent that the economy is reoriented around a quaternary supra-circuit in which extractive arbitrage becomes both routine and a dominant strategy of accumulation. The literature on shareholder value (Froud et al. 2006; Pike 2006), for example, demonstrates how short-termist, financially extractive corporate governance have undermined previously locally-embedded business models. In so transforming the temporalities of capital, financialization has altered the nature of the spatial fix. 
It is by now an established fact that there is a surfeit of overaccummulated capital in the global economy, though its cause is disputed. Former Federal Reserve Chair Ben Bernanke set the orthodoxy by blaming a 'global savings glut' while the traditional 'monopoly capital' interpretation of surplus absorption problems underpinned by low demand has gained traction recently under the guise of former IMF Chief Economist Lawrence Summers' arguments that the economy is suffering 'secular stagnation' (see Foster 2016). Within the geography literature this condition of endemic capital overaccumulation has been characterized as a 'global search for yield' (Ashton 2009) or 'wall of money' (Fernandez and Aalbers 2016) relying particularly on housing markets for release.

The spatial fix to overaccumulation relies on the secondary circuit having a longer temporality. Yet as investors take advantage of the fixed nature of alternative asset-classes by making them more liquid to invest in (Van Loon and Aalbers 2017), they shorten those turnover times thereby exacerbating the problem. The profits fictitious capital offer by pulling conjectured future value into present circulation themselves provide an outlet for overaccumulated capital (Amin 2018; Jessop 2000), leading Fernandez and Wigger (2016) to characterize this temporal moment of switching as a 'financialization fix'. However, this turn to finance serves to multiply the money seeking outlet in the system even as it shortens the average acceptable turnover times of investment.

This is the central contradiction at the heart of Harvey's 'fix' concept: a crisis of overaccummulation is deferred only by creating the conditions for a bigger crisis. The extensive reliance on fictitious capital in this fix intensifies capitalism's crisis tendencies both by introducing speculative bubbles driven by the endogenous dynamics of the credit market (Minsky 1982) and by enhancing the geographic reach of any crisis creates new glocalized networks of interdependencies. The quaternary circuit of financial capital switching therefore defers the crisis of overaccumulation by transforming the temporalities of capital but, in the process, brings to the fore potentially more catastrophic contradictions. 
Pre-proof version

\section{The Contradictions of Capital Liquidity}

Before the 2007-09 global financial crisis, economic orthodoxy asserted that the creation of complete liquidity through financial innovation made the market more efficient and stable because it facilitates price discovery and risk transfer. As such, the collective rationality of the markets could be brought to bear on everything and equilibrium achieved (Jessop, 2015; Turner, 2015). However, rather than creating a more stable economy this created the conditions in which the internal contradictions of credit-mediated capital liquidity could fully develop. In this section, I draw on Minsky's financial instability hypothesis to outline the contradictions of an economy reliant on easy credit.

In the Fordist era finance played an intermediary role in an economy dominated by commodity production, with the limited extension of fictitious capital meaning that prices retained a plausible link to the realization of value through socially necessary labour time. However, in an economy awash with fictitious capital prices become dependent on primarily subjective - indeed, performative (per Callon and Muniesa 2005; Mackenzie 2006) - judgements as to future value capture. As a result, financial assets' prices can come to follow their own logics of circulation rather than reflecting the underlying socio-spatially embedded income streams they ostensibly reflect. Market participants have limited incentive to dampen this separation because their profits lie in relative rather than absolute value - that is, the profit over what they paid for it that it can be sold to the next person for, rather than the intrinsic value of the underlying revenue stream (Frydman and Goldberg, 2011; Pistor, 2013). The point here is that even if an economic actor is pessimistic about the absolute value of an asset it is rational to overpay anyway as long as there is a 'greater fool' who is willing to pay more, while extensive fictitious capital creation enables such actors to pay prices based on values that do not exist yet and may never.

Rather than the rational allocation of risk that equilibrium theory posited would result from complete liquidity, then, it has instead produced a tendency towards asset inflation as the system skews to the most optimistic participant who can gain financing. And this is exponential because the rising asset-prices these credit-fuelled purchases enable themselves fuel expectations of further rises while providing greater collateral with which to borrow against. Credit issuance can 
thus drive asset appreciation while asset appreciation facilitates further credit issuance (Mian and Sufi, 2014; Minsky, 1982; Turner, 2015). In this way an asset's circulation as fictitious capital can come to obscure its demarcation of actual revenue-generating potential (that is, absolute value), creating the conditions for what Minsky (1982) termed 'Ponzi financing' whereby the availability of credit determines the valuation of assets as their price becomes dependent on the potential for refinancing.

Furthermore, the introduction of financial innovations such as derivatives have turned this tendency of finance towards credit-driven asset price inflation into a systemic feature. Derivatives are securities whose value derives from an underlying asset. They allow for the abstraction of certain 'attributes of assets' through which ownership 'takes the form of isolated exposures to specific risks' (Wigan 2009: 167). The subsequent commodification of risk (ibid) allows financial institutions and companies to create debt while trading away the increased exposure to market volatility that debt implies. This ability to trade risk away removes incentives for those with embedded, situated knowledge of the underlying revenue streams to dampen speculation: companies or financial actors can produce leverage and sell the exposure to market volatility it creates to someone with a greater appetite for risk (Mian and Sufi 2014).

As Pani and Holman (2014) argue, however, this is predicated on imbuing risk management methods with the 'supernatural ability to eliminate uncertainty'. Risk is a quantified probability which is, as such, tradable and manageable. In the process of asset abstraction the uncertain multiplicities of space in which an asset's revenue-generating capacities are bound are made legible to investors as risk (Wigan 2009) through a range of calculative practices which themselves become performative sources of value (Callon and Muniesa 2005; Mackenzie 2006). Yet while risk management methods are effective in controlling for stochastic fluctuations they provide little protection from non-random and systemic bubbles. This is exactly what Minksy's financial instability hypothesis posits as credit driven asset appreciation becomes self-reinforcing - something that not only confounds risk management, but that risk management itself contributes through the illusion of having eliminated uncertainty. Conversely, when the uncertainties of space confound the expectations which risk management are based on and the 
credit bubble stops inflating, a 'Minksy moment' can occur in which asset deflation, credit defaults and the drying up of liquidity become mutually reinforcing.

When losses become non-random like this risk management strategies no longer work to eliminate the exposure by allocating it but serve to spread the crisis. Derivate hedging, for example, creates counterparty risk (wherein one of the actors who swapped the risk default on their obligations) and therein the conditions for what Nanumyan et al. 2015 call 'failure cascades' as defaults by one party causes other business to fail (see also Bryan and Rafferty 2006). Methods such as derivative hedging are thus rational in terms of mitigating a company's immediate risk but creates new interdependencies between otherwise unrelated regions and sectors, so magnifying any eventual crisis (Harvey, 2006; Jessop, 2015; Pani and Holman, 2014; Pike and Pollard, 2010).

The core contradiction of the quaternary circuit is that, once removed from socio-spatial constraints through capitalized abstraction (see Birch 2017; Mann 2018; Pryke and Allen 2019), financial assets come to follow their own logics of circulation in financial markets. Reliance on fictitious capital introduces the credit bubble dynamics described by Minsky (1982; see Jessop 2015; Mian and Sufi 2014), which are reinforced by financial innovations such as derivatives (Bryan and Rafferty 2006; Wigan 2009). This is an important departure from the equilibrium theory assumptions that underpin risk management models because it means that fluctuations and asset price swings are not stochastic (i.e., random) fluctuations around the underlying absolute value but a systemic divorce between relative and absolute value. Thus the apparent overcoming of spatial fixity under financialized capitalism is only partial because it relies on the inflation of credit bubbles which are liable to burst when the idiosyncrasies of the sociospatial process confounds expectations.

\section{Peel Ports Group: Case-Selection and Methodology}

A key feature of this argument that the inflation of credit bubbles is systemic to the financial system is that at each step described market participants are acting rationally in the economistic sense of profit-maximization. While economic 'rationality' here is a construct (Mackenzie 2006), it is also a useful theoretical device because if actors acting optimally in this sense still create the 
conditions for crisis then this establishes that the problem is an inherent feature of the system; rather than, e.g., being an actor-centred psychological problem of incomplete information or participants' 'bounded rationality' (Frydman and Goldberg 2011; Kahneman 2003). Rather, it suggests that it is a matter of one of the most fundamental contradiction of a market society: the self-interest of profit-maximising market actors amalgamate as self-destructive collective system dynamics (Harvey 1978).

Exploring this in the context of the corporate leverage crisis, I investigate the 'logic of leverage' (Konings 2018) through which a relatively risk-averse company implements financial capital switching through extensive debt, in the process pointing to how this rational profit-maximising behaviour contributes to creating the conditions for a general crisis. While it is already established that there is a dangerous corporate leverage bubble across the economy (Bank of England 2018), unpacking this process of financialized debt production from the perspective of a single company allows us to better anticipate how these contradictions may manifest qualitatively. This approach is in line with that advocated by Bryan et al. (2017) who argue that the unbundling of assets across time and space mean established conceptual containers such as nations are no longer sufficient so the corporation itself is now an important basic unit of analysis.

I focus on Peel Ports Group's whole business securitization (WBS as a 'paradigmatic case' in that it encapsulates and allows exploration of important general characteristics (per Flyvberg, 2006). The general characteristics I explore in Peel's WBS are how capital liquidity is created out of spatial fixity through corporate leverage and how this may feed into financialized capitalism's crisis tendencies. A case of infrastructure financialization is particularly revealing because Harvey (2014) points to infrastructure as a paradigmatic example of the fixity/motion contradiction, in that it entails the immobilization of large concentrations of capital investment to facilitate the motion of commodities. Yet financialization has entailed that this capital investment is no longer immobilized, with infrastructures' transformation into a liquid asset-class being 'one of the great themes' of financial markets in the decade following the financial crisis (Knight and Sharma, 2016; see Van Loon and Aalbers, 2017). Examining the financial engineering techniques used in creating capital liquidity from something previously considered intractably fixed, in Harvey's sense, allows exploration of how capital switching has been routinized through extensive leverage. 
I construct the case through a close reading of Peel Ports Group's accounts, corporate reports and documents of registration filed with the UK's 'Companies House' and the Isle of Man's 'Companies Registry'. I was able to overview the initial investors in the RREEF fund because each investing company was registered as a shareholder in an Isle of Man holding company, so allowing me to build a list of who invested and how many shares they held in the fund.

However, a limitation of this case is that, as is common in corporate financial arrangements (see, e.g., Fernandez and Wigger 2017), Peel Ports Group transfer a significant portion of its profits to a parent company based in an offshore secrecy haven (the Cayman Islands). Without insight into the parent company's accounts I cannot definitively assess Peel's leverage as a whole. I do not purport to offer a case of a company that is overleveraged, necessarily, but to show the logic and mechanisms by which they effect credit mediated capital switching, and point to the ways in which such strategies create the conditions for crisis more generally.

\section{God's assets: building an infrastructure group}

'Mr Whittaker describes infrastructure companies as 'God's assets'... No one can take away land, air or water. And if the port doesn't work, you still have the land' (Andrew Simpson, Peel Managing Director)

The Peel Group initially acquired port companies in northwest England to attain their undervalued land portfolios and build a megamall on a particularly attractive plot owned by the Manchester Ship Canal Company (see Ward and Swyngedouw 2018). After this culminated in the lucrative 'Trafford Centre' shopping mall which Peel securitized for $£ 610 \mathrm{~m}$ in 2000 , the company set about valorising the other assets it had built up in its extensive portfolio. Amidst a general trend of financialising private equity actors entering the infrastructure sector and leveraging up (see Allen and Pryke 2013; Deruytter and Derudder 2019; O'Brien et al. 2019; O’Neil 2019; Pryke and Allen 2019; Rodrigue et al. 2011), Peel built a ports group from the early 2000s onwards that included Glasgow's Clydeport, the Manchester Ship Canal and the Port of Salford. Most significantly it acquired the Port of Liverpool's owners, the Mersey Dock and Harbour Company (MDHC), taking it off the stock market as their private company in a 2005 deal valued at $f 771 \mathrm{~m}$. In adding the Port of Liverpool to its portfolio, Peel Ports Group became Britain's second-largest 
ports group after Associated British Ports (itself subject to takeover by a Goldman Sachs-led consortium in 2006).

After the MDHC takeover, Peel restructured the port companies it had acquired. It separated the port operations from their land-holdings, pooled together the ports into one company and sold $49.9 \%$ of the subsequent ports group, Peel Ports, to Deutsche Bank's alternative infrastructure arm, RREEF, in 2006. A private equity fund based in Deutsche Bank's London subsidiary, the RREEF fund channels institutional investors' capital into a portfolio of European infrastructure projects. Table 1 shows the range of investors in the $€ 2$ billion RREEF private equity fund. The predominant role of pension and insurance funds (in this case mostly German, Dutch, Danish, and British) is reflective of how the demand of these large pools of capital seeking long-term outlets have undergirded the transformation of infrastructure into an asset-class (Clark 2000; Van Loon and Aalbers 2017). 
Table 1. Investors at the closing of RREEF's Pan-European Private Equity Investment Fund, August 2007

\section{Company Name} Share in fund (\%) Type of investor

Pension fund of government

Stichting Pensioenfonds ABP

RREEF Pan-European Infrastructure Feeder Arbejdsmarkedets Tillaegspension

Stichting Bewaarder Interpolis Pensioenen

Infrastructure Pools

ScottishPower Pension Scheme

BAE Systems Pension Funds Trustees Limited

Church of England Investment Fund

Lansforsakringar Liv Försäkringsaktiebolag

Achmea Pensioenfonds \& Levensverzekeringen

Deutsche Asset Management Limited

Veolia UK Pension Trustee Limited

Cardif Assurance Vie

Manweb Group of the ESPS

Royal Ordnance (Crown Service) Pension

Scheme Trustees Limited

Sogecap

Bank of Tokyo-Mitsubishi UFJ, Ltd

Stichting Rabobank Pensioenfonds

Merimieseläkekassa

SCOR Global P\&C

Commission de la Caisse commune de retraite des employés de la Ville de Montréal 1697125 Ontario Inc

UBC Investment Management Trust Inc. Landessbank Hessen-Thüringen Girozentrate

Bedrijfstakpensioenfonds voor het Schilders-,

Afwerkings- en Glaszetbedrijf

Stichting Bedrijfstakpensioenfonds

voor de Media PNO

OP Life Assurance Company Limited

RBC Dexia Investor Services

LCF Edmond de Rothschild Prifund

Avalon Holdings Inc

Caixa Geral de Depositos SA

State Street Trust \& Banking Co., Ltd as Trustee

Infrastructure Holding S.á.r.I

Stichting Pensioenfonds ARCADIS Nederland

Dexia Insurance Belgium SA/NV

Japan Trustee Services Bank Limited

Dexia Life \& Pensions Luxembourg SA

20.8 employees

Feeder fund channeling investment

20.1 from 20 German insurance companies

10.4 Pension fund

5.9 Pension fund

5.2 Pension fund of power company

4.3 Pension fund of BAE systems Investment fund of the

3.9 Church of England

2.6 Insurance company conglomeration

2.6 Pension fund

2.1 Investment bank

1.6 Pension fund for water company

1.6 Insurance company

1.6 Pension fund for power companies

1.3 Pension fund for mapping agency

1.3 Insurance company

1.3 Bank

1.2 Pension fund

1.0 Pension fund for seafarers

1.0 Insurance company

1.0 Pension fund for the City of Montreal

0.9 Ontario Teacher's Fund Investment fund of

0.8 University of British Columbia

0.8 Commercial Bank Pension fund for painters,

0.8 decorators \& glazers

0.8 Pension fund for media companies

0.6 Insurance company

0.6 Pension fund

0.6 Investment fund

0.5 Waste management company

0.5 Public bank

0.5 Custodian bank

0.5 Unknown

0.5 Pension fund of a consultancy

0.4 Insurance company

0.3 Trust Bank

0.2 Insurance \& pension fund
Headquarters

Heerlen, Netherlands

Frankfurt, Germany Hillerød, Denmark

De Meern, Netherlands

Glasgow, Scotland

Farnborough, UK

London, UK Stockholm, Sweden Appeldoorn, Netherlands New York, USA London, UK Nanterre, France London, UK

Farnborough, UK Paris, France Tokyo, Japan De Meern, Netherlands Helsinki, Finland Paris, France

Montreal, Canada Toronto, Canada

Vancouver, Canada Frankfurt, Germany Zeist, Netherlands Hilversum, Netherlands Niemenmäki, Finland London, UK Luxembourg Warren, Ohio, USA Lisbon, Portugal Tokyo, Japan Luxembourg Arnhem, Netherlands Brussels, Belgium Tokyo, Japan Luxembourg

Note: Share in fund percentage is based on total of known capital contributions. Sources: RRREF PanInfrastructure Fund LP6 statements 2005, 2006, 2007a, 2007b; www.bloomberg.com; www.avalonholdings.com; www.scottishpower.co.uk; 
Here infrastructure's fixed nature was attractive as 'patient capital' investors were attracted to its longer turnover times and the fact that it tends not to correlate with other assets as investors sought to diversify their portfolios (Clark 2000; O'Neill 2019; Van Loon and Aalbers 2017). This is an expression of the spatial fix (Harvey 2006) under financialized capitalism and one that intensified following the financial crisis as quantitative easing kept the system liquid but investors sought 'quality' assets such as infrastructure (Ashton et al. 2012; Knight and Sharma 2016; O’Brien et al. 2019; O’Neill 2019).

In these new assemblages of relations required to implement financialized capital switching, wealth chains and multi-scalar networks are introduced through the range of institutional investors in the sale to RREEF through which the port was incorporated into an investment fund portfolio including other infrastructural assets across Europe. However, the primary means by which the port's revenues were extracted was through the company's securitized debt-financing arrangements, pulling in a range of issuing banks and bond-holders of their corporate debt. It is through this credit-mediation that Peel dissembles the underlying value creation processes of the infrastructure into its investment qualities to circulate on the global financial market (see Pryke and Allen 2019).

\section{Liquefying the Port of Liverpool}

In 1970 the Mersey Dock and Harbour Company became one of the first major British public companies to be privatized. As a legacy of the way in which that tentative early privatization was arranged, the port still had public interest provisions in the constitution of the company that forbade a leveraged buyout. As such, Peel negotiated a relatively new financial innovation, 'Whole Business Securitization' (WBS) because it effectively allowed a leveraged buyout without technically violating these covenants (Linklaters 2012). Instead of offering bonds secured against the revenue from a specific asset, in a Whole Business Securitization (WBS) the bonds are backed by all of the cashflows across the business regardless of the source of that revenue. Further, in the case of insolvency of the business, the noteholders can maintain the right to control assets and receive funds from operations. This boosts the rating of the debt and so allows more extensive borrowing at a cheaper rate than would otherwise be the case. 
While Peel engineered a WBS in order to effect a leveraged takeover of MDHC, it immediately absorbed that company into its wider ports group so lowering its overall leverage with the group's other port assets. In extending the WBS to revenues across the whole ports group, therefore, its 2013 refinancing was 'the first genuine WBS in the port industry' (Linklaters 2012). Amidst a difficult funding environment in which bank debt was difficult to source - for instance, Peel's creditor in the original WBS, Bank of Scotland Corporate, had recently been nationalized in a bailout following the 2007-09 financial crisis - Rothschild investment bank arranged a securitized bond structure. They did so as a US private placement because that market had a record year as institutional investors sought safe assets, and so the infrastructure company could get better rates there than on the public markets (Russel-Walling 2013). To do so, Rothschild organized a facility in which 11 banks invested and the private loan notes were moved from bank to bank depending on the interest rate available in their jurisdiction (Linklaters 2012). The solution to difficulties in financing its short-term borrowing after the crisis, then, was to intensify liquidity creation through credit in a facility that further formalizes and routinizes capital switching.

Borrowing against the whole business in this way also allows for a significant level of gearing/leverage. Indeed, it enables Peel to fund the whole business through debt in a state of 'negative gearing'. Gearing is the amount of debt in relation to owners' investment (equity). A term typically used in property investment, 'negative gearing' describes a situation in which the income from assets is less than the expenses incurred, so that the business is funded by debt. Following the creation of a ports group and their mortgaging of its cash-flows in the WBS deal, Peel Ports Limited has been negatively geared. This is sustainable if the underlying asset appreciates, so that eventually the cash flows from the business outgrow the interest repayments and ultimately pay down the loan.

Thus in the accounts for the year following that in which Peel structured its ports group as Peel Ports, the company's debt to equity ratio was $415 \%$. Instead of being funded by profits and equity the business' main source of capital is debt, so that rather than paying tax on capital employed (based on the profit announced) the company's revenue is invested in paying the interest on the debt and a loss declared. Peel Ports consistently declare an accumulated deficit even while taking 
money out of the business via dividends paid to a Cayman Island holding fund. Without exception, these dividends are a multiple of the post-tax profit the company announces, within a range of $120-1760 \%$. These dividends are written down as a loss so along with the high-interest payments on the debt mean that company is run at a loss and Peel Ports pay less tax than if those dividends had been retained as profit.

In a low-interest environment this tax-efficient debt-financing can be a big saving: effectively, the cost of capital attained to fund the business is much cheaper as it is acquired at the prevailing interest rates. Thus, interest on Peel Port Group's circa $£ 1$ billion in bank loans was determined by LIBOR (the interbank short-term lending rate), which was an average of $4.771 \%$ in 2005 , the year of the port's leveraged takeover, while corporation tax on profits were then $19 \%$. Meanwhile, the dividends are funnelled to the Caymans Islands which has no corporation tax, and the losses announced in the UK and their accumulated deficit ( $£ 672$ million in the 2016 accounts) can be offset against any capital gains tax they would have to pay on future sales of property or equity. This ability to write off the cost of debt against tax amounts to a statesubsidization of debt-financing (i.e., tax breaks on debt mean that it is more profitable to take it out than not), encouraging such corporate leveraging and subsequent credit bubbles (Mian and Sufi, 2014).

Figure 1 demonstrates this with an overview of the Peel Ports Group Consolidated Profit and Loss Account, which shows how the net profit is arrived at; and Reconciliation of Shareholder Debt, which explains the difference between this net profit and the deficit the company announces; from Peel Ports Group accounts 2008-2014. The graph shows the interest payments on Peel's debt taking up most of its operating profit, with the majority of the remainder paid out to the Cayman Island Parent company as a dividend: 


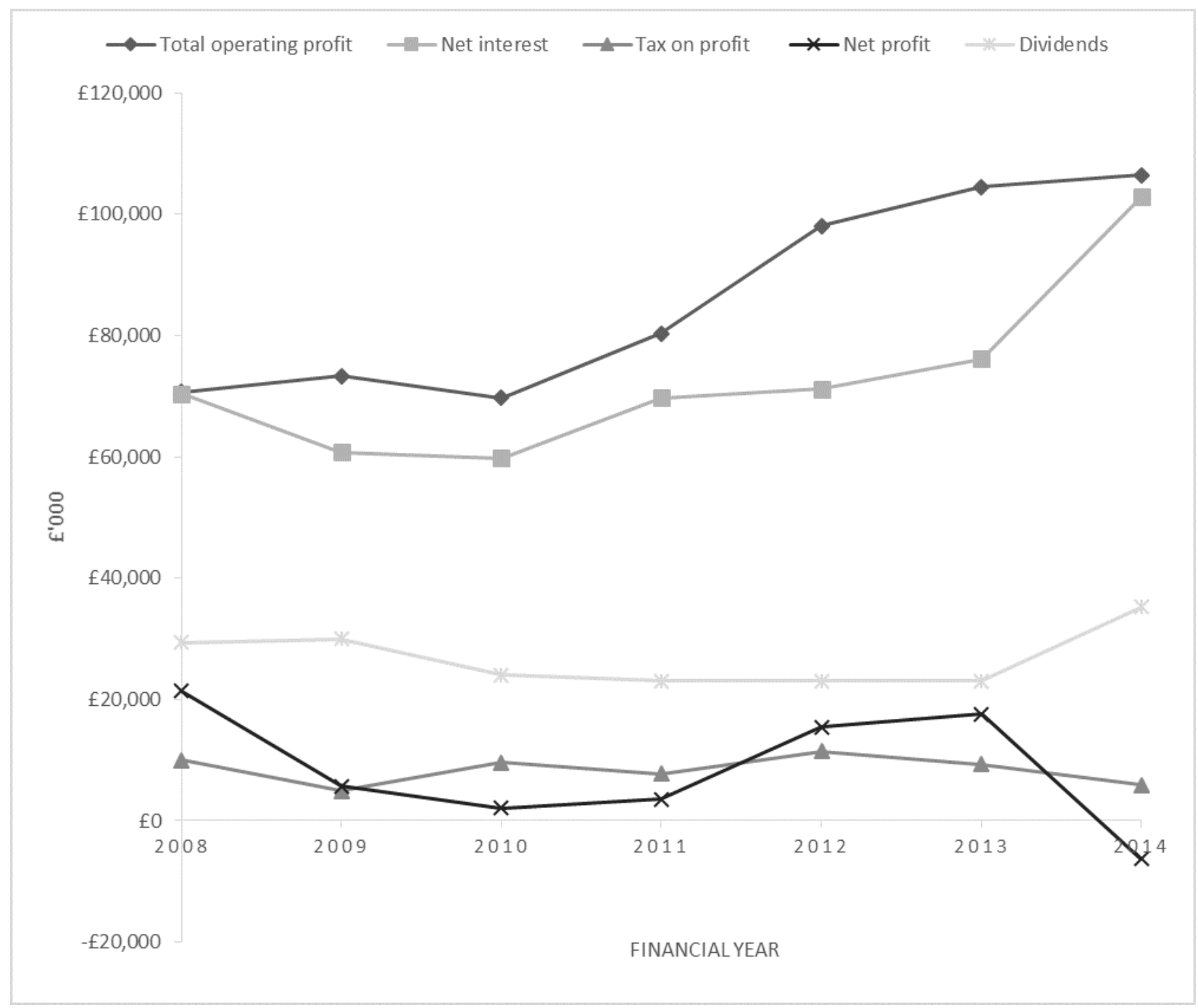

Figure 1. Extracting Profits through Debt and Dividends: Peel Ports Group 2008-14. Note: net profit is calculated before dividends. Sources: Peel Ports Shareholder FinanceCo Limited 2008-2012; Peel Ports Group Limited 2013-14.

Demonstrating how such extensive fictitious capital mobilization changes the temporality of capital through chronic financial capital-switching, WBS and negative gearing pulls in what Minsky considered to be an advanced stage of crisis in 'Ponzi financing', in which '...even the repayment of interest depends on continuing asset price inflation' (Jessop 2015: 2), as a routine financial instrument. This pre-packaged Ponzi financing is a rational strategy, releasing liquidity at a lower cost of capital thanks to the combination of low-interest rates and effective statesubsidy to debt-financing that writing off tax against interest payments provides. However, such borrowing still presents a sizeable gamble on the asset's appreciation as well as interest rate 
fluctuations, so risk management is important to calibrate exposure and so make the leverage tolerable.

\section{Fetishising Risk}

The creation of capital liquidity through debt renders Peel Ports Group more vulnerable to market volatility, particularly in interest rates (see directors report, Peel Ports Group Accounts 2018: 9). Rather than the sort of derivative speculation that proved the ruin of many during the financial crisis (see Aalbers et al., 2017; Pani and Holman, 2014; Van Meeteren and Bassens, 2018), Peel Port Group's use of the instrument appears to be limited to hedging against this exposure by trading away the specific risks arising from its debt-structure. The way such risk management creates the conditions for crisis is that it facilitates greater leverage by spreading the resulting exposure across otherwise unrelated parties, so creating new, deep interdependencies across the global system. In the event of a counterparty default this introduces the potential for failure cascades if and when the commodified risk turns out to be mis-priced as uncertainty intrudes.

Peel Ports Group uses two main forms of interest rate swaps to offset its exposure. An interest swap is a contract wherein Peel agrees to pay a counterparty's interest rates for a given period and they Peel's. The first such swap converts the bulk of its debt ( $£ 612$ million) to a fixed interest rate from a floating one tied to LIBOR (the base rate at which banks lend to each other). The second converts interest on $£ 352$ million of its loans to a rate linked to the UK retail price index (UKRPI) meaning that the interest rate paid rises with inflation over time. While the first swap removes any risk of fluctuations by simply paying a fixed interest rate, the second ties their payments to an indicator of the growth of the UK economy. 
Another important instrument they use is currency swaps. A significant portion of WBS loan notes were denominated in dollars so Peel Ports Group uses currency swaps to convert this from dollar into sterling debt as this involves exchanging the currency at the given exchange rate on the date of the swap contract, and exchanging it back on the maturity of the contract at the same rate regardless of currency movements. Like converting interest rates from floating to fixed, this allows Peel a fixed price based on when they made the WBS deal and so removes the risk of exchange rate fluctuations. In a context of sterling's sharp decline following the UK's 2016 'Brexit' vote to leave the European Union, this has meant whereas Peel would otherwise be using its sterling revenue to pay down dollar debt its finances have not been directly impacted. This illustrates how derivatives can be an effective tool allowing a company to calibrate its exposure to market volatility.

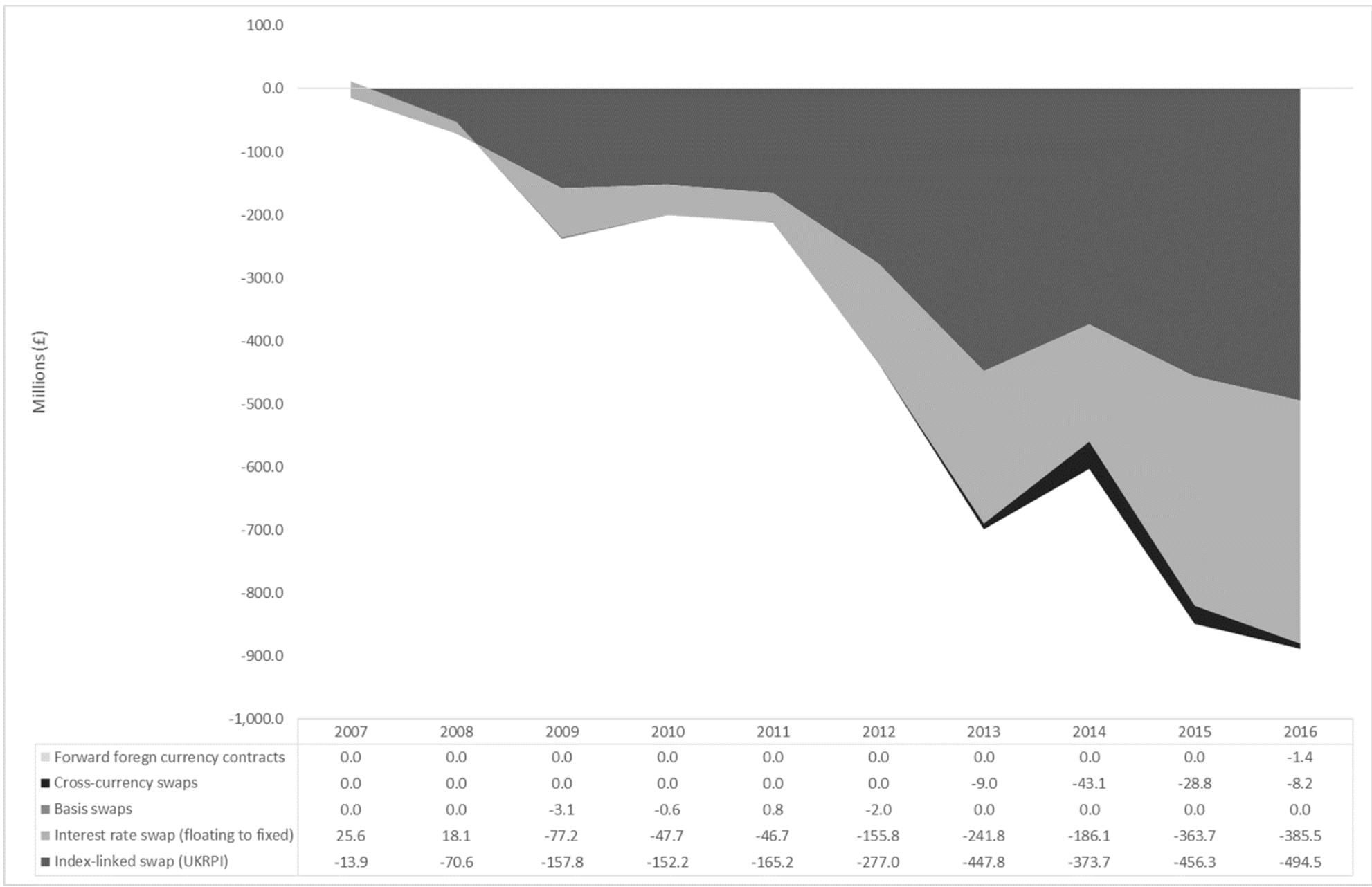

Figure 2: Fair Value of Derivative Instruments: Peel Ports Group 2007-16. Sources: Peel Ports Shareholder FinanceCo Limited 2007-2012; Peel Ports Group Limited 2013-18. 
Yet this is also a good example of how the 'fiction of distance from risk' (Pani and Holman 2014) afforded by derivatives makes it rational for otherwise non-speculatively actors to take on large debts. Because it could trade away its exposure to a party with a greater appetite for risk, Peel took on greater leverage than they were likely to tolerate otherwise to take advantage of the lower cost of capital of debt-financing and the demand in US private placement markets.

However, as Pani and Holman (2014) argue, this rests on the fetishization of affording risk management the supernatural qualities of eliminating uncertainty. If the commodified risks which derivatives represent (Wigan 2009) turn out to be mispriced - or not priceable - due to uncertainty, these risk management strategies and the leverage they facilitated will be precarious indeed. And in the political economic restructuring of recent years, uncertainty is very much back. For Peel's finances in particular, the UK's surprise referendum result to leave the European Union in June 2016 is likely to have a profound impact on the ports sector, as $44 \%$ of Britain's exports and $53 \%$ of its imports are with the EU (statistic for 2017, from Ward 2019). The Port of Liverpool could gain from this as the backlogs created by border checks at existing EU-oriented ports makes the more circuitous route to northern UK ports a more competitive option for cargo (and have already seen rising demand on this basis, Saul 2019). More speculatively, the Atlantic-facing port could be a beneficiary of any prospective free trade deal with the US.

However, Peel's highly leveraged position means that significant damage to Britain's economy or financing environment would likely offset any such gains. Indeed, a 2018 analysis by the Bank of England projected that an extreme worst-case 'disorderly' exit without a deal with the EU would provoke a deeper recession than that following the 2007-09 global financial crisis, projecting there could be a sharp $8 \%$ fall in GDP, inflation rising up to $6.5 \%$, interest rates to $4 \%$ and sterling falling below parity with the dollar (Bank of England, 2018). Previously considered highly unlikely, a no deal exit appears eminently plausible at the time of writing in summer 2019. Whether this will look like the worst-case 'disorderly' projection or the Bank's less catastrophic no-deal option of 'disruptive' remains to be seen. Regardless of the outcome, spatial fixity - in the sense of the idiosyncrasies of revenues dependent on specific sociospatial processes - is very much back as investors are disabused of the fetishization of uncertainty as manageable risk. 


\section{Discussion: Peel Ports in the Quaternary Circuit}

My argument in this paper is that the fixity/motion tension Harvey identified as animating the geographies of capitalism has been transformed through financialization into an even more intense one of spatial fixity/capital liquidity (see Gotham 2009; 2012). As the barriers to investment in the built environment have been overcome through financial innovation, geographies of capital circulation changed correspondingly from being characterized by convulsive 'switching crises' (Harvey 1978; 1982/2006) to chronic switching in which financial arbitrage itself became the prime locus of profitability and outlet for overaccumulated capital (Aalbers 2008; Fernandez and Wigger 2016). The resultant 'quaternary circuit' of capital switching operates through separate space-times to that of production (Bryan et al. 2017; Seabrooke and Wigan 2017) and is most directly shaped by the speculative dynamics of fictitious capital endogenous to credit markets, as described by post-Keynesians (Mian and Sufi 2014; Minksy 1982; Turner 2015). The case of Peel Ports Group's securitization illustrated this in showing how the temporality and geography of the circulation of the port's revenues were transformed through extensive leverage, and in how the conditions for crisis inhere in the "logic of leverage' (Konings 2018) adopted.

Peel Ports Groups' financial engineering of the Port of Liverpool exemplified the geographical and institutional restructuring involved in abstracting an asset for global circulation, as well as the routinization of arbitrage in the resulting financial circuits. The case illustrated the way in which such financing arrangements have overcome the traditional fixities of national regulatory regimes, particularly in Peel's RREEF partnership wherein a significant portion of the port's revenues are transferred via debt instruments to offshore tax and secrecy havens ultimately for disbursal for consumption by pensioners in northern Europe (see Table 1). The extent to which credit-mediated capital switching has become a quotidian, if contingently constructed, feature of businesses' financial structures is apparent in the facility between 11 banks moving Peel Ports' debt notes to whichever jurisdiction had the most favourable interest rates.

The case also highlights how temporalities of circulation are transformed in the process of massive fictitious capital creation. Peel pulled all of the expected future revenues of the port into 
present circulation through whole business securitization, to the point where borrowing is required to keep up with the interest rates. This mirrors Minsky's description of Ponzi-financing but instead of being the final stages of crisis he described, a WBS offers such extensive leverage as a strategic choice to maximize value extraction. One material way such leverage transforms the temporality of infrastructure financing is that short-term financial performance is now far more important because sufficient revenues are required to meet annual interest payments and refinance short-term debt bonds.

That such strategies have been generalized across the economy would appear to be wellevidenced in warnings of a growing corporate leverage bubble of comparable scale to that of the sub-prime mortgage crisis (Bank of England, 2018a). The case of Peel contributes to this argument by demonstrating that such leveraging has not only been made routine but is 'rational' for a company seeking to maximize profit within a loose credit-environment. Although seemingly relatively risk averse, Peel did not have to avoid overindebtedness but could instead calibrate their exposure to its risks through derivative hedging.

But as Pani and Holman (2014) argue, this rests on the fetishization of imbuing risk management with the supernatural ability to eliminate uncertainty. The case offers a concrete example of how this fetishization is misguided in the uncertainty that Brexit introduces to the UK economy and correspondent financing environment. Should Britain experience the sharp drop in GDP and rise in interest rates the Bank of England predicted in the event of a disorderly no deal, Peel's debtfinancing will make it extremely vulnerable - especially if the crisis culminates in a 'Minsky moment' of deflationary pressure on assets and a tightening of credit. Should this result in default, their use of derivative hedges means that parties otherwise completely removed from Britain's crisis are now exposed through counterparty risk. In this way, the overcoming of spatial fixity by systemic financial capital switching, represented here in Peel's port securitization, serves to magnify and extend the inevitable crisis. 


\section{Conclusion}

In this paper, I followed Aalbers (2008) in conceptualizing the ostensibly complete liquidity of financial markets as the ongoing implementation of credit-mediated circuits of capital switching. This capital switching frame allowed me to synthesize otherwise disparate strands of critical finance studies. In particular, I focused on how capital liquidity is created from spatial fixity (Gotham 2009; 2012) through financialized infrastructures of asset abstraction via global wealth chains (Bryan et al 2017; Seabrooke and Wigan 2017; see Pryke and Allen 2017; Sokol 2017). Further, I argued, the dependence of this asset abstraction on fictitious capital, and therein speculative and performative judgements as to future value (Callon and Muniesa 2005; Mackenzie 2006; Mann 2018), unleashes Minskian Ponzi-financing dynamics (Jessop 2015; Turner 2014; Mian and Sufi 2014; Minksy 1982). By interpreting these approaches to finance within Harvey's dialectical critique of capitalism's inherent crisis tendencies, I highlighted the contradictions of financialized capital liquidity. Specifically, pointing to how the prolific systematization of risk this financialized liquidity depends on creates the conditions for a much larger crisis when the uncertainties of space are ultimately reasserted.

Peel Ports' WBS offered an exemplar not of crisis but the construction of financialized circuits of capital switching and, in that, how the conditions of the corporate leverage crisis have been created through common strategies to maximize profit and minimize risk in an economy awash with easy credit. In the process, the paper has shown how a capital switching framework integrates analysis of the socially-mediated nature of market-making and the new temporalities of financialized wealth chains within a wider theorization of the territorial dynamics of capitalism.

In doing so, this also serves as an argument for the adoption of a capital switching perspective in approaching current debates in financial and urban geography. To maintain a capital switching perspective on financialization is to insist not only on understanding the socially constructed nature of the separation of liquid financial assets from their underlying revenues, but also the socio-spatiality of this separation and its specific dynamics rooted in the contradictions of capital. It is to conceptualize financial globalization as a contested, uneven process of geographical and institutional restructuring around finance-oriented accumulation strategies of arbitrage and 
extraction. Doing so casts new light on existing literature, allowing us to place recent contextually 'thick' studies of contestation over capital switching in particular locales (e.g., Kaika and Ruggiero, 2015; 2016; Weber 2015) as constituent parts of global economic movements.

This attention to meso-scale political economic restructuring within a wider theorization of the changing spatio-temporalities of capital circuits is key to understanding what Alami (2018) terms the 'relational geographies of money power' in which the seemingly objective territorial flows of finance are understood to operate through and reinforce extractive class, neocolonial, racial and gender hierarchizations (see also Kaika and Ruggiero, 2016). A capital switching frame focuses attention on this fundamental role of power and contestation in the territoriality of capital markets as they articulate with the contradictory dynamics of the value-form; in particular, capital's innately geographical tension between fixity and motion (Gotham 2009; Harvey 1982). Further work is required on the power-laden nature of financial capital switching, particularly in order to understand emergent geopolitical tensions as the de-territorializing logic of leverage increasingly gives way to the conflict-ridden re-territorialization of its spatialized crises. It should not be forgotten that in Harvey's development of capital switching theory, the culmination of capital's destructive inner contradictions is global conflagration. 


\section{$\underline{\text { References }}$}

Aalbers, M.B. 2008. The financialization of home and the mortgage market crisis. Competition and Change 12(2):148-166.

Aalbers, M.B. 2009. Geographies of the financial crisis. Area 41(1):34-42

Aalbers, M.B., Loon, J., Fernandez, R. 2017. The financialization of a social housing provider. International Journal of Urban and Regional Research 41(4), 572-587.

Allen, J. and Pryke, M. 2013. Financialising household water: Thames Water, MEIF, and 'ringfenced' politics, Cambridge Journal of Regions, Economy and Society, 6(3): 419-439

Alami, I. 2018. On the terrorism of money and national policy-making in emerging capitalist economies. Geoforum 96, November: 21-31

Amin, S. 2018. Modern Imperialism, Monopoly Finance Capital, and Marx's Law of Value: Monopoly Capital and Marx's Law of Value. Monthly Review Press: New York

Ashton, P. 2009. An Appetite for Yield: The Anatomy of the Subprime Mortgage Crisis. Environment and Planning A: Economy and Space 41(6): 1420-144.

Ashton P., Doussard M., and Weber R. 2012. The Financial Engineering of Infrastructure Privatization. Journal of American Planning Association. 78(3): 300-312.

Bank of England. 2018a. Financial Stability Report. https://www.bankofengland.co.uk//media/boe/files/financial-stability-report/2018/november2018. pdf?la=en\&hash=7239DE596DD5DB14BEB17E1141C2CDEB73A8623C\#page $=56$ accessed $05 / 04 / 2019$

Bank of England. 2018b. EU withdrawal scenarios and monetary and financial stability. A response to the House of Commons Treasury Committee. https://www.bankofengland.co.uk//media/boe/files/report/2018/eu-withdrawal-scenarios-and-monetary-and-financialstability.pdf?la=en\&hash=B5F6EDCDF90DCC10286FC0BC599D94CAB8735DFB accessed 05/04/2019

Beauregard, R. 1994. Capital switching and the built environment: United States, 1970-89. Environment and Planning A 26 (5): 715-732.

Birch, K. 2017. Rethinking Value in the Bio-economy: Finance, Assetization, and the Management of Value. Science Technology Human Values. 42 (3): 460-490.

Brenner, N. 1998. Between Fixity and Motion: Accumulation, Territorial Organization and the Historical Geography of Spatial Scales. Environment and Planning D 16 (4): 459-481

Bryan, D. and Rafferty, M. 2006. Capitalism with derivatives. Basingstoke: Palgrave Macmillan

Bryan, D. Rafferty, M. and Wigan, D. 2017. Capital unchained: finance, intangible assets and the double life of capital in the offshore world. Review of International Political Economy 24 (1): $56-86$ 
Callon, M., and Muniesa, F. 2005. Peripheral Vision: Economic Markets as Calculative Collective Devices. Organization Studies 26 (8): 1229-1250.

Clark, G. 2000. Pension Fund Capitalism Oxford: Oxford University Press

Deruytter, L., \& Derudder, B. (2019). Keeping financialisation under the radar: Brussels Airport, Macquarie Bank and the Belgian politics of privatised infrastructure. Urban Studies 56(7): $1347-1367$.

Elson, P., 2010. Downturn and interest charges hit Peel ports. Liverpool Daily Post. 22 November.

European Central Bank. 2019. May 2019 Financial Stability Review. https://www.ecb.europa.eu/pub/financial-stability/fsr/html/index.en.html accessed $01 / 06 / 2019$

Feagin, J. 1987. The Secondary Circuit of Capital: office construction in Houston, Texas. International Journal of Urban and Regional Research 11 (2): 172-192

Fernandez, R. \& Aalbers, M.B. 2016. Financialization and housing: Between globalization and Varieties of Capitalism. Competition and Change 20 (2): 71-88

Fernandez, R. and Wigger, A. 2016. Lehman Brothers in the Dutch offshore financial centre: the role of shadow banking in increasing leverage and facilitating debt Economy and Society 45 (3-4): 407-430

Flyvbjerg, B. 2006. Five Misunderstandings About Case-Study Research. Qualitative Inquiry. 12 (2): 219-245.

Foster, J. B. 2016. Monopoly Capital at the Half Century Mark. Monthly Review 68: 3 (JulyAugust)

Froud, J. Johal, S. Leaver, A. Williams, K. 2006. Financialization and Strategy: Narrative and Numbers London: Routledge

Frydman, R. and Goldberg. 2011. Beyond Mechanical Markets: Asset Price Swings, Risk, and the Role of the State. Princeton: Princeton University Press.

Gotham, K.F. 2009. Creating Liquidity out of Spatial Fixity: The Secondary Circuit of Capital and the Subprime Mortgage Crisis. International Journal of Urban Regional Research 33 (2): 355-371

Gotham, K.F. 2012. 'Creating Liquidity Out of Spatial Fixity: The Secondary Circuit of Capital and the Restructuring of the US Housing Finance System' in, Sub-Prime Cities: The Political Economy of Mortgage Markets ed. M. Aalbers, 25-52, Oxford: Wiley-Blackwell.

Hall, W. 2005. Mersey agrees docks deal with Peel. Financial Times June 9

Harrison, M. 2004. Mersey Docks soars on CVC bid approach. The Independent 11 November

Harrison, J. 2013. Rethinking City-Regionalism as the Production of New Non-State Spatial Strategies: The Case of Peel Holdings Atlantic Gateway Strategy. Urban Studies 51 (11): 2315-2335. 
Harvey, D. 1978. The urban process under capitalism: a framework for analysis. International Journal of Urban and Regional Research 2: 101-131.

Harvey, D. 2006 [1982]. The Limits to Capital. Oxford: Basil Blackwell.

Harvey, D. 2014. Seventeen Contradictions and the End of Capitalism. London: Profile Books

International Monetary Fund. 2018. World Economic Outlook: Challenges to Steady Growth. October 2018. https://www.imf.org/en/Publications/WEO/Issues/2018/09/24/worldeconomic-outlook-october-2018 accessed 05/04/2019

Jessop, B. 2000. The crisis of the national spatio-temporal fix and the tendential ecological dominance of globalizing capitalism. International Journal of Urban and Regional Research 24 (2): 323-360.

Jessop, B. 2015. Hard cash, easy credit, fictitious capital: Critical reflections on money as a fetishized social relation. Finance and Society 1 (1): 20-37

Kahneman, D. 2003. Maps of Bounded Rationality: Psychology for Behavioral Economics. American Economic Review, 93 (5): 1449-1475.

Knight, E. and Sharma, R. 2016. Infrastructure as a traded product: a relational approach to finance in practice. Journal of Economic Geography 16 (4): 897-916

Konings, M. 2018. Capital and Time: For a New Critique of Neoliberal Reason. Stanford: Stanford University Press.

Kutz, W. 2016. The eurozone crisis and emerging market expansion. International Journal of Urban and Regional Research 40 (6): 1075-1093.

Linkaters. 2012. Linklaters advises Peel Ports on whole business securitisation www.linklaters.com/News/LatestDeals/2012/Pages/Linklaters-advises-Peel-Ports-whole-businesssecuritisation.aspx

MacKenzie D. 2006. An Engine, Not a Camera: How Financial Models Shape Markets. Cambridge: MIT Press.

Mann, G. 2018. Equation and Adequation: The World Traced by the Phillips Curve. Antipode 50 (1): 184-211.

Markortoff, K. The sub-prime timebomb is back - this time companies are lighting the fuse. The Observer 12/01/2019 https://www.theguardian.com/business/2019/jan/12/subprimetimebomb-back-companies-lighting-the-fuse accessed 4/05/2019

Mian, A. and Sufi, A. 2014. House of Debt Chicago: University of Chicago Press

Minsky, H. 1982. Can “It” Happen Again Oxford: Routledge

Nanumyan, V., Garas, A., and Schweitzer, F. 2015. The Network of Counterparty Risk: Analysing Correlations in OTC Derivatives. PlosOne https://doi.org/10.1371/journal.pone.0136638 
Pre-proof version

Newman, K. 2009. Post-Industrial Widgets: Capital Flows and the Production of the Urban. International Journal of Urban and Regional Research 33 (2): 314-331

O’Brien, P., O’Neill, P., and Pike, A. 2019. Funding, financing and governing urban infrastructures. Urban Studies. 56 (7): 1291-1303.

O'Neill, P. 2019. The financialisation of urban infrastructure: A framework of analysis. Urban Studies. 56 (7): 1304-1325.

Osborne, A. 2005. Whittaker closes in on Mersey Docks. The Telegraph http://www.telegraph.co.uk/finance/2904942/Whittaker-closes-in-on-Mersey-Docks.html

Ouma, S. 2018. This can('t) be an asset class: The world of money management, "society", and the contested morality of farmland investments. Economy and Space A. DOI: $10.1177 / 0308518 X 18790051$

Pani, E. and Holman, N. 2014. A Fetish and Fiction of Finance: Unraveling the Subprime Crisis. Economic Geography 90: 213-235.

Peel Ports Group Limited. 2013. Report and Financial Statements for the year ended 31 March 2012

Peel Ports Group Limited. 2014. Report and Financial Statements for the year ended 31 March 2012

Peel Ports Group Limited. 2015. Report and Financial Statements for the year ended 31 March 2015

Peel Ports Group Limited. 2016. Report and Financial Statements for the year ended 31 March 2016

Peel Ports Group Limited. 2017. Report and Financial Statements for the year ended 31 March 2017

Peel Ports Group Limited. 2018. Report and Financial Statements for the year ended 31 March 2018

Peel Ports Shareholder FinanceCo Limited. 2007. Report and Financial Statements for the year ended 31 March 2007.

Peel Ports Shareholder FinanceCo Limited. 2008. Report and Financial Statements for the year ended 31 March 2008

Peel Ports Shareholder FinanceCo Limited. 2009. Report and Financial Statements for the year ended 31 March 2009

Peel Ports Shareholder FinanceCo Limited. 2010. Report and Financial Statements for the year ended 31 March 2010

Peel Ports Shareholder FinanceCo Limited. 2011. Report and Financial Statements for the year ended 31 March 2011

Peel Ports Shareholder FinanceCo Limited. 2012. Report and Financial Statements for the year ended 31 March 2012 
Pike, A. 2006. Shareholder value' versus the regions: the closure of the Vaux Brewery in Sunderland. Journal of Economic Geography 6(2):201-222

Pike, A. and Pollard, J. 2010. Economic Geographies of Financialization Economic Geography 86(1):29-51

Pistor, K. 2013. A legal theory of finance. Journal of Comparative Economics 41 (2): 315-320

Pryke, M. and Allen, J. 2019. Financialising urban water infrastructure: Extracting local value, distributing value globally. Urban Studies 56(7): 1326-1346.

Rodrigue, J., Notteboom, T. and Pallis, A. 2011. The financialization of the port and terminal industry: revisiting risk and embeddedness. Maritime Policy and Management 38(2):191213

RREEF Pan-European Infrastructure Investment Fund LP. 2006. LP6 10 August

RREEF Pan-European Infrastructure Investment Fund LP. 2007a. LP6 19 April

RREEF Pan-European Infrastructure Investment Fund LP. 2007b. LP6 29 June

RREEF Pan-European Infrastructure Investment Fund LP. 2007c. LP6 30 July

RREEF raises \$2.7bln European infrastructure fund. Reuters August 62007

RREEF Research. 2009. Global Ports: Trends and Opportunities. www.rreef.com last accessed $05 / 03 / 2012$

Russell-Walling, E. 2013. Rothschild navigates Peel Ports to calm waters. The Banker 1/02/13 http://ec2-54-72-50-240.eu-west-1.compute.amazonaws.com/CommentProfiles/Deals/Rothschild-navigates-Peel-Ports-to-calm-waters?ct=true accessed 06/01/2019

Saul, J. 2019. Peel Ports expands amidst Brexit trade uncertainty. Reuters 20/03/19 https://uk.reuters.com/article/uk-britain-eu-peelports/peel-ports-expands-amid-brexit-tradeuncertainty-idUKKCN1R123S accessed 03/01/2019

Seabrooke, L. and Wigan, D. 2017. The governance of global wealth chains. Review of International Political Economy 24 (1): 1-29.

Sokol, M. 2017. Financialization, financial chains and uneven geographical development: Towards a research agenda. Research in International Business and Finance 39 (B): 678685

Swyngedouw, E. 2005. Governance Innovation and the Citizen: The Janus Face of Governancebeyond-the-State. Urban Studies. 42 (11): 1991-2006.

Torrance, M. 2009. The Rise of a Global Infrastructure Market through Relational Investing. Economic Geography 85: 75-97

The Lawyer. 2005. Linklaters, Travers finalise buyout of Mersey Docks and Harbour Co. https://www.thelawyer.com/issues/20-june-2005/linklaters-travers-finalise-buyout-ofmersey-docks-and-harbour-co/ 
Torrance, M. 2008. Forging glocal governance? Urban infrastructures as networked financial products International Journal of Urban and Regional Research 32(1) :1-21.

Turner, A. 2015. Between Debt and the Devil: Money, Credit, and Fixing Global Finance Princeton University Press: Princeton

Van Loon, J. and Aalbers, M. 2017. How real estate became 'just another asset class': the financialization of the investment strategies of Dutch institutional investors. European Planning Studies 25(2): 221-240

Van Meeteren, M., and Bassens, B. 2018. 'Chasing the phantom of a 'global endgame': the role of management consultancy in the narratives of pre-failure ABN AMRO' in Hoyler, M., Parnreiter, C., and Watson, A. (eds.) Global City Makers: Economic Actors and Practices in the World City Network. Cheltenham, UK: Edward Elgar Publishing

Walks, A. 2010. Bailing out the Wealthy: Responses to the Financial Crisis, Ponzi Neoliberalism, and the City. Human Geography 3(3)

Ward, C. and Swyngedouw, E. 2018. Neoliberalisation from the Ground Up: Insurgent Capital, Regional Struggle, and the Assetisation of Land. Antipode 50(4): 1077-1097.

Ward, M. 2019. Statistics on UK-EU Trade. Commons Briefing. Number 7851, 11 January

Weber, R. 2015. From Boom to Bubble Chicago: University of Chicago Press

Wigan, D. 2009. Financialisation and Derivatives: Constructing an Artifice of Indifference. Competition \& Change, 13(2): 157-172.

Wijburg, G. 2019. Reasserting state power by remaking markets? The introduction of real estate investment trusts in France and its implications for state-finance relations in the Greater Paris region. Geoforum, Volume 100, March, 209-219

Wilcox. Negative Gearing. http://www.wilcoxrealestate.com.au/negative_gearing.htm

Yrigoy I. 2018. State-Led Financial Regulation and Representations of Spatial Fixity: The Example of the Spanish Real Estate Sector. International Journal of Urban and Regional Research 42(4): 594-611. 